INDEPENDENT JOURNAL OF MANAGEMENT \& PRODUCTION (IJM\&P)

http://www.ijmp.jor.br

v. 12, n. 1, January-February 2021

ISSN: 2236-269X

DOI: 10.14807/ijmp.v12i1.1301

\title{
THE SERVICE-DOMINANT LOGIC IN MARKETING: AN ESSAY WITH TEACHERS AND STUDENTS OF THE MASTER'S IN ADMINISTRATION
}

\author{
Maicon da Silva \\ Universidade de Santa Cruz do Sul, Brazil \\ E-mail: maicon213@bol.com.br
}

Submission: 3/4/2020

Revision: 3/19/2020

Accept: 3/29/2020

\section{ABSTRACT}

This study responds to a theoretical essay, where it sought to analyses the dominant logic of service in marketing and its contextualization, based on studies initiated by exponents such as Vargo and Lusch in 2004. In other words, this new logic interpreted that value is constructed from the perspective of value in individual or social use. Also, it was sought to bring findings of the evolution of the concept of marketing, because it has been the concern of researchers in the area over the past decades. Still, since 2004, theories have been developed about this orientation of the "new logic". In this period, the proposers of the Vargo and Lusch theory reviewed the Foundational Assumptions (FPs) of the "Service Dominant Logic" (SDL), where some years later was added an eleventh FP written in the article of (Vargo \& Lusch, 2016) "the co-creation of value is coordinated through institutions managed by an actor and institutional arrangements". In this way, this essay approached private higher education through reports from teachers (teachers) and students (students) of the Master's Degree in Administration at a University located in the Pardo River Valley/RS, more precisely the classroom of that course, addressing the interactive relationships between the parties in the process of teaching learning and knowledge construction. Finally, studies based on the dominant logic of service in marketing and the co-creation of value, consists of resuming studies of the last decade in the marketing area, providing advances for integrative issues, where companies need to differentiate themselves in relation to their competitors, seeking to offer the best products and/or services. 
DOI: 10.14807/ijmp.v12i1.1301

Keywords: Service-Dominant; Marketing; Foundational; Premises; Master; Administration; Value Co-creation

\section{INTRODUCTION}

One of the research challenges related to Marketing Administration is to understand the importance of the media, because access to information allows customers to have quick and detailed knowledge about a particular product and/or service. This possibility is based on the perspective of the dominant logic of marketing service, where these new perspectives have made the customer increasingly demanding, causing companies to seek closer ness with them in order to identify their needs and desires.

From the Dominant Logic of the Marketing Service, Vargo and Lusch (2004) defend the exchange of intangible assets - represented by skills, expertise and processes - to the detriment of a vision exclusively focused on the exchange of tangible goods, i.e., manufactured products. This approach, which puts the client in a service orientation position, also sees him as a co-creator, and this experience adds value to the process and suggests new strategies that ensure their greater satisfaction.

According to Pine II and Gilmore (1998, p. 97) "the experiences of customers provided by companies is what will matter most as goods and services become commodities." These authors state that the experiences have typically been interpreted by economists as services, however, experiences constitute a distinct economic offer of services as well as these are of products. They argue that services as well as products before them become increasingly commoditized and thus experiences emerged as the next stage of them call value generation (Pine Ii \& Gilmore, 1998, p. 98).

Thus, the idea of co-creation of value that is this is given emphasis on the Dominant Logic of the Service (LDS). Proposal that has been discussed since 2004, having as main exponents Vargo and Lusch. In this logic, it was interpreted that the value is constructed from the perspective of value in use created by the user individually or socially during the use of resources and processes (Grönroos \& Voima, 2013). Such an interpretation would break with the argument of b2c - business to consumer interactions (Vargo \& Lusch, 2008).

At the risk of interpretations that would denote an imbalance in the relationship between offer or and consumer, which would maintain the value still being created by one of the parties, the latest (LDS) review presents a reordering of the lexicon that considers the process of creating value like A2A - actor to actor - where operative resources act as strategic benefits 
DOI: 10.14807/ijmp.v12i1.1301

and no longer as a competitive advantage (Vargo \& Lusch, 2016). As a reason, the authors point out that they are not failing to consider competition, but that this should be a secondary motivator while co-creation by the provision of services is the main one.

On the other hand, the vision based on The Dominant Logic in Service is shredding economic principles and this new perspective is gaining notoriety in the literature, especially in the marketing area, where it proposes a new framework in which services represent the economic exchange systems, countering commodity-based vision (Moraes \& Costa, 2012).

To provide personalized experiences (Thomke \& Von Hiippel, 2002; Prahalad \& Ramaswamy 2000; Von Hiippel, 1986) firms must create opportunities for customers to experiment with them and decide how much engagement they want to have in creating a given experience. Thus, the center of gravity of innovation remains in technology or product reinforcing the dominant logic of value creation. Instead, the center of gravity must move to individual co-creation of experiences. According to the author, in the universe of experience the individual (client) is the center (Ramaswamy, 2003).

In view of these questions, the present study, which is responsible for a theoretical essay, aims to highlight the importance of the dominant logical theme of service in marketing for private higher education, and it is possible for universities to think about actions that differentiating themselves from competitors.

Thus, the importance of this article and its contributions to the academic environment, aligns with the different contexts related to the dominant logic of service in marketing, but specifically in private higher education, in which a new trend arises in provision of educational services focused on the concepts of marketing administration, where it is necessary to immerse ourselves in the process of seeking new services that universities can offer to customers (students), meeting their needs and desires.

Thus, we sought to analyze the concepts and premises of the dominant logic of service in marketing and its contextualization's, understanding the state of the art on the theme proposed in this research. It is therefore noteworthy that the debate is situated. It is necessary to advance in the understanding of the phenomenon of marketing focused on services. For this, discussions about the theoretical essay proposed in this article are presented, seeking to investigate ways and/or possibilities for further studies.

\section{THE EVOLUTION OF THE MARKETING CONCEPT}


DOI: 10.14807/ijmp.v12i1.1301

Before the early 1960s, marketing was seen as a mere synonym for sales within large companies in the United States of America - despite many academics, consultants and analysts defining marketing quite differently. Because of the functions and meanings attributed to marketing by the high summit of large companies, marketing was had by many - in several countries, but mainly in Europe in the early 1970s - as a resource used by large companies (in especially large U.S. companies) for the purpose of manipulating consumers, citizens and business employees (Faria, 2008).

For Faria (2008), from the mid-1970s, recognizing that much of what was said about marketing was not effectively practiced, academics and some organizations had to redefine marketing. These new definitions emphasize the strategic character of marketing and strongly challenged the 'dark' side of the concept and the dominant tactical approach. As one of the results of this process of academic redefinition, marketing is defined today both as a managerial function and as a philosophy of administration or social principle.

According to Rocha and Christensen (1999), marketing is not only a managerial function, dedicated to the adjustment between the organization's offer and the specific demands of the market, using as a tool a set of principles and techniques. It can also be seen, as a social process, by which the supply and demand of goods and/ or services are regulated to meet social needs.

Thus, even before they were objects of study, organizations already used Marketing concepts in their business. The idea of producing something that meets the needs of others and delivers the manufactured product in exchange for another product or monetary value is as old as one imagines (Lazzaretti, 2013). According to Terblanche (2005), it is possible to observe product and service marketing practices since before 7.000 a.c. (barter, mercantilism, enlistment in armies). However, the marketing discipline has less than a century of existence.

Therefore, define what is evolution of the marketing concept and what its scope has been the concern of researchers in the area over the past decades. The American Marketing Association (AMA) changed and refined several times the concept of marketing, seeking to explain and adjust the definition and scope of the area to reflect the complexity of the performance of managers and academics, in an increasingly competitive environment and, therefore, the evolution of the marketing concept (Darroch et al., 2004).

For a better understanding, in the last decades of the 20th century, marketing thinking was fragmented and, in light of the time, in a superficial analysis, this seemed to be a reasonable 
DOI: 10.14807/ijmp.v12i1.1301

characterization (Vargo \& Lusch, 2004). According to the authors, this view was questioned, suggesting that perhaps, at the time, the marketing thought was not fragmented, but rather, evolving into a new dominant logic (that of the service), which is increasingly present, far from the exclusive vision the exchange of tangible goods (manufactured things) and towards an exchange of intangible assets (skills, expertise and processes), thus moving towards a more comprehensive and inclusive logic.

After an extensive research and development process conducted by Robert Lusch and Greg Marshall in 2004, the AMA's definition was changed to "an organizational function and a set of processes for creating, communicating and delivering value to customers and for the management of relationships with them, so that it benefits the organization and its stakeholders” (Darroch et al., 2004). For Sheth and Uslay (2007), replacing the term exchange for value co-creation in the 2004 definition of the AMA draws attention to the fact that, when focusing on the exchange, it is considered only the creation of value at the time of exchange, of the transaction.

In front of this situation, Oliveira, Damacena and Brambilla (2014) choose the term Dominant Logic of the Service, refining it as the consumer's conception evolves as a valued co-creator, also restructuring other premises aimed at this situation. Thus, the Dominant Logic of the Service should not have its interpretation restricted to traditional conceptualizations that treat it as residual (all that is not very tangible), something offered to improve a good (service as added value), or what has been classified as service industries (health, government, education). Thus, in the next section will be addressed the theory of the dominant logic of the service in marketing.

\section{DOMINANT LOGIC OF MARKETING SERVICE}

The traditional marketing logic, centered on products and whose focus is the transaction, that is, the transfer of possession by sale, no longer makes sense in current times. This change of focus in the marketing area had already been announced in the 1960s, when Levitt (1960) revealed that errors in business perception so of the real needs of customers led to conditions of low competitive capacity (Barguil, 2012). For Levitt (1960), the idea of selling at any cost should be excluded from the mental model of companies, since the important thing is that they focus on the customer and their present and future satisfaction rather than centralizing efforts only on the production of goods. 
DOI: 10.14807/ijmp.v12i1.1301

LDS is also the basis for the development of Service Science, led by IBM, which articulates human and organizational understanding with technological and business understanding to categorize and explain service systems (its construct how they interact and evolve to co-create value. Service Science considers LDS a conceptual foundation for providing perspectives, vocabulary and premises for building a theory that underpinned a scientific approach to advance the design and proposal of innovations for service systems (Maglio \& Spohrer, 2013).

Thus, the logic that permeates all subjectivity of what is expected and what is obtained is understood by Vargo and Lusch as The Dominant Logic of the Service (LDS). LDS's proposal emerged in 2004 not as a new theory, but as a philosophical reorientation to marketing (Vargo \& Lusch, 2007; Brambilla, 2013). The exchange-based consumer approach is based on its central objective of the exchange that, in addition to sustaining the economy, supports social structures (Kotler \& Levy, 1969).

Since transactions involving companies, markets and economies are primarily exchanging services, it has been said that marketing thinking should start from a theoretical construction with principles in the logic of the service that considers the value of the good as a value that encompasses the participation of the different actors involved (Vargo \& Lusch, 2004; Vargo \& Morgan, 2005; Vargo, Maglio \& Akaka, 2008; Brambilla, 2013; Grönroos \& Voima, 2013).

By shifting value to experience, relationships between company and client favor cocreation (Ballantyne, 2004; Prahalad \& Ramaswamy, 2004; Vargo \& Lusch, 2004; Ballantyne \& Varey, 2006). For Prahalad and Ramaswamy (2004), increasingly active consumers become valuable co-creators by interacting with the company. This definition is in line with that adopted by LDS, where service is understood as "the application of specialized skills (operational resources - knowledge and skills) through instruments, processes and performances for the benefit of another entity itself" (Vargo \& Lusch, 2008b, p. 26).

Logic Dominated by the Service does not focus on the economic system from the point of view of the production-consumption of goods, and the essential thing in this exchange model is the exchange of service for service, being the service being a process in which one actor benefits another and/or takes advantage of the interaction (Lusch \& Vargo, 2014). According to these authors, the process of serving involves the application of knowledge and skills for the benefit of another entity or itself. 
INDEPENDENT JOURNAL OF MANAGEMENT \& PRODUCTION (IJM\&P)

http://www.ijmp.jor.br

v. 12, n. 1, January-February 2021

ISSN: 2236-269X

DOI: 10.14807/ijmp.v12i1.1301

Best (2009) reiterates the idea that companies need to look beyond available products and prices and see the shopping experience in a complete way. The idea of mass collaboration is introduced in due course. According to the author, customers (prosumers, partners, suppliers and employees) should be involved in the process of creating value to the customer, and consequently in creating value for the company. The greater the specialization of delivery, the greater the interdependence between the parties and the more relational the "exchange contract", thus seeking long-term interaction with customers.

The interesting thing about the new logic is that it does not abandon the concept of product logic, it just adds the concept of service. Products and services remain important, as they constitute the service provision mechanism (Vargo \& Lusch, 2004a). The product can be understood as encapsulated knowledge, to provide a desired service by the consumer. Customers buy the service or benefit that these goods perform for them. According to the new logic, consumers are little concerned about the physical object itself, but with what this object will bring you benefits and satisfaction. This should then be the focus of companies: increase the benefits of the service. The product, therefore, becomes a knowledge transmitter (Vargo \& Lusch, 2004a).

The focus of the Dominant Logic of the Service on understanding what problems customers face would be the starting point to propose solutions, regardless of an offer or product for these problems. Thus, marketing becomes the provider of solutions for the tasks customers need to do (Baker \& Hart, 2008). Thus, this logic is represented by Foundational Premises (PFs), addressed in the next section. As already referenced in this study, for example, in the case of co-creation, PFs represent axes of development of the dominant logic of service.

\subsection{Foundational Assumptions of The Dominant Logic of Service}

The dominant logic of the service is represented through premises, which, according to Vargo and Lusch (2004a) propose the evolution of marketing, based on the greater interaction between consumer and company, which is reflected in equality between agents in the search for solutions. Vargo and Lusch $(2006$; 2008; 2016) warn of the evolution of concepts previously worked in marketing, pointing out eight fundamental premises for understanding this study.

To previous premises, in 2006 the authors added the PF9 premise, according to which "all social and economic actors are resource integrators". Vargo and Lusch (2008) modified six founding premises of marketing and launched the tenth, PF10, which provides that "the value 
DOI: 10.14807/ijmp.v12i1.1301

is always determined in a unique way is phenomenological by the beneficiary". Subsequently, the authors altered four founding premises of marketing and released the eleventh and last premise, PF11, which states: "value co-creation is coordinated through institutions managed by an actor and institutional arrangements" (Vargo \& Lusch, 2016, p. 72).

Based on the discussions generated between 2004 and 2016 on Dominant Service Logic, Etierre (2018) presents in his study "Co-creative Process between Company, Athlete and Consumers" the initial foundational marketing premises. Preserving the temporal criteria, the eight premises present in Vargo and Lusch (2004a) present; then the ninth premise added in Vargo and Lusch (2006) and the tenth premise found in Vargo and Lusch (2008). Finally, the eleventh premise present in the most recent study by Vargo and Lusch (2016) is denoted, with the explanation of its logical evolution. Next, we can observe the evolution of the eleven premises proposed by these authors. In 'Chart 1', the presentation of the ten PFs in their updated versions.

- PF1: The application of skills and expertise is the fundamental unit of exchange (Vargo \& Lusch, 2004a).

Evolved into service is the fundamental basis of exchange (Vargo \& Lusch, 2008). The substitution occurred due to two reasons: 1) the unit is related to product logic, such as an output; and 2) by simplifying, because for authors, skills and knowledge for the benefit of others is a lexicon related to service. This premise states that the service is exchanged for service.

\section{- PF2: Indirect transactions mask the fundamental trading unit.}

It evolved into indirect transactions masking the fundamental basis of the exchange. According to the authors, the change is necessary for the same reason as the previous premise, where the term unit is related to the dominant logic of goods (Vargo \& Lusch, 2008).

With growth, organizations lose focus on consumers and the service they provide. The integration of money, goods, organizations and vertical marketing systems are just trading vehicles that mask the trading unit (Vargo \& Akaka, 2009).

\section{- PF3: Goods are distribution mechanisms for the provision of services.}

Knowledge is the fundamental source of competitive advantage and goods are not common exchange denominators (Vargo \& Lusch, 2004a). This premise remained unchanged 
DOI: 10.14807/ijmp.v12i1.1301

in the authors' publications (Vargo \& Lusch, 2016). Consumers want products depending on the services they provide; for example, cars are seen as providers of the locomotion service.

\section{- PF4: Knowledge is the fundamental source of competitive advantage.}

The premise has been changed to operating resources are the fundamental source of competitive advantage (Vargo \& Lusch, 2008). The authors point out that knowledge and skills are synonymous with an operative resource. And finally, operating resources are a key source of strategic benefit (Vargo \& Lusch, 2016). The operating resources are difficult to copy, thus generating a competitive advantage (Day et al., 2004).

\section{- PF5: All economies are service savings.}

The premise remained unchanged. Tangible goods (products) are mechanisms for provision of service, and service and its consumers are the essence of economic activity (Lusch, Vargo \& O'brien, 2007). Therefore, the fundamental unit of exchange are the mental and physical skills related to the provision of the service (Brambilla \& Damacena, 2011).

\section{- PF6: The consumer is always a Co-producer.}

This premise has been changed for the consumer is always a co-creator of value (Vargo \& Lusch, 2008). The change occurred due to the fact that co-production is associated with product logic (customer participation only of the production process), while the co-creation of value is a broader term that incorporates co-production, where the consumer is active in the process of generation of value (Brambilla \& Damacena, 2011).

\section{- PF7: The company can only make value propositions.}

Evolved into the company cannot deliver value, can only offer value proposition (Vargo \& Lusch, 2008) and finally the company cannot deliver value, can participate in the creation and value proposition offers (Vargo \& Lusch, 2016).

The product that is not sold has no value, a service provider (product) without consumers has no function. The consumer should not be seen only as a target, as he is responsible for determining the value (COLD, 2014). The company alone has A2A relationships (within the company), cannot deliver value, only provide services and co-create value along with the consumer (Vargo \& Lusch, 2016).

\section{- PF8: A service-centric vision is consumer-oriented and relational.}


DOI: 10.14807/ijmp.v12i1.1301

This premise has evolved into a service-centric vision inherently consumer-oriented and relational vision (Vargo \& Lusch, 2008) and, finally, a service-centric vision is inherently beneficiary-oriented and relational (Vargo \& Lusch, 2016).

Goods as inanimate elements do not promote relationships, because the service is determined according to the benefits created by itself; logic becomes inherently centered on the consumer and the relationship. In Vargo and Lusch (2016), the service vision is centered on the beneficiary and not just on the final consumer, since this is an approach to LDS.

- PF9: Organizations exist to integrate and transform micro specialized skills into complex services that are demanded in the market.

All social and economic actors are resource integrators; not only consumers and companies propose value, but also all stakeholders linked to the process (Frow \& Payne, 2011).

- PF10: The value is always unique and phenomenologically determined by the beneficiary, that is, the value is determined by the consumer at the time of use.

For Grönroos and Voima (2013), the value depends on the consumer's situation and the time of use, that is, products that have already been experienced and expectation of the future are contextual elements related to value for the consumer (Helkkula, Kelleher \& Pihiström, 2012).

- PF11: The co-creation of value is coordinated through institutions managed by an actor and institutional arrangements.

To refer to the interrelated sets of institutions which together constitute a coherent relative assembly that contributes to the activity of co-creation of value in service ecosystems (Vargo \& Lusch, 2016).

The Dominant Logic of the Service is presented through the Eleven Foundational Premises (PFs), which represent axes of development. As noted earlier, the eight PFs cited by Vargo and Lusch (2004a) were altered in later articles (Vargo; Lusch, 2004a; 2006; 2008; 2016), with changes in terms initially used. In addition, two new premises were proposed, thus giving rise to ten $\mathrm{PFs}$.

Vargo and Lusch (2008) argue that the service is a process that uses resources for the benefit of another party, usually the customer/consumer. For a better understanding of the PFs of the 'Dominant Logic of the Service', they are still up to date and commented. Table 1 below synthesizes and extends previous explanations. 
INDEPENDENT JOURNAL OF MANAGEMENT \& PRODUCTION (IJM\&P)

http://www.ijmp.jor.br

v. 12, n. 1, January-February 2021

ISSN: 2236-269X

DOI: 10.14807/ijmp.v12i1.1301

Table 1: Foundational Premises (updated) of the Dominant Logic of Marketing Service.

\begin{tabular}{|c|c|c|}
\hline \multicolumn{2}{|r|}{ Updated Foundational Assumptions } & PFs Comments \\
\hline $\begin{array}{c}\text { PF1 } \\
(2004 \mathrm{a})\end{array}$ & $\begin{array}{l}\text { Service is the fundamental basis of } \\
\text { exchange. }\end{array}$ & $\begin{array}{l}\text { Services are exchanged for services, and represent } \\
\text { the economic analysis unit. }\end{array}$ \\
\hline $\begin{array}{c}\text { PF2 } \\
(2004 a)\end{array}$ & $\begin{array}{l}\text { Indirect exchanges mask the fundamental } \\
\text { exchange base. }\end{array}$ & $\begin{array}{c}\text { The provision of the service has a complex } \\
\text { integration of elements. }\end{array}$ \\
\hline $\begin{array}{c}\text { PF3 } \\
(2004 \mathrm{a})\end{array}$ & $\begin{array}{l}\text { Goods are mechanisms for distributing } \\
\text { the provision of service. }\end{array}$ & $\begin{array}{l}\text { The value is linked to the use, through the } \\
\text { provision of the service. }\end{array}$ \\
\hline $\begin{array}{c}\text { PF4 } \\
(2004 \mathrm{a})\end{array}$ & $\begin{array}{l}\text { Intangible resources are the fundamental } \\
\text { source of competitive advantage. }\end{array}$ & Competitive advantages guide the competition. \\
\hline $\begin{array}{c}\text { PF5 } \\
(2004 \mathrm{a})\end{array}$ & All economies are service savings. & $\begin{array}{l}\text { Service, in the singular, better characterizes the } \\
\text { idea of the logic of marketing in service. }\end{array}$ \\
\hline $\begin{array}{c}\text { PF6 } \\
(2004 a)\end{array}$ & $\begin{array}{c}\text { The consumer is always a co-creator of } \\
\text { value. }\end{array}$ & $\begin{array}{l}\text { Value co-creation occurs interactively in all } \\
\text { service contacts. }\end{array}$ \\
\hline $\begin{array}{c}\text { PF7 } \\
(2004 \mathrm{a})\end{array}$ & $\begin{array}{c}\text { The company cannot deliver value, only } \\
\text { offer value propositions. }\end{array}$ & $\begin{array}{l}\text { Value propositions are only possible in } \\
\text { interaction. Unilaterality does not generate value. }\end{array}$ \\
\hline $\begin{array}{c}\text { PF8 } \\
(2004 a)\end{array}$ & $\begin{array}{l}\text { A service-centric view is inherently } \\
\text { consumer-oriented and is also relational. }\end{array}$ & $\begin{array}{l}\text { The service is determined by the customer through } \\
\text { the benefits determined by the customer in the co- } \\
\text { creation of value. }\end{array}$ \\
\hline $\begin{array}{c}\text { PF9 } \\
(2006 a)\end{array}$ & $\begin{array}{l}\text { All social and economic actors are } \\
\text { resource integrators. }\end{array}$ & The context of value co-creation is integrative. \\
\hline $\begin{array}{l}\text { PF10 } \\
(2008)\end{array}$ & $\begin{array}{l}\text { Value is always unique, and } \\
\text { phenomenologically determined by the } \\
\text { beneficiary. }\end{array}$ & $\begin{array}{c}\text { Value is idiosyncratic, referring to experience, } \\
\text { contextual and loaded with meaning for } \\
\text { consumers. }\end{array}$ \\
\hline
\end{tabular}

Source: adapted by the author of Vargo and Lusch (2004a); Lusch and Vargo (2006a); Vargo and Lusch (2008);

vargo and lusch (2016).

In view of the above, all this was synthesized by the creation of four axioms, from which the other PFs were related. In 2016, Vargo and Lusch added the eleventh Foundational Premise, adding a fifth axiom. The creation of these axioms (Lusch and Vargo, 2014) and the modifications proposed in the 2016 article emphasize the details allowing a broader perception for theory, mainly through the review of concepts. The evolution of the concepts described is synthesized in Table 2.

Table 2: Evolution from eleven premises to the five axioms

\begin{tabular}{|c|l|}
\hline \multicolumn{1}{|c|}{ Axioms } & \multicolumn{1}{c|}{ Description } \\
\hline Axioms 1/PF1 & Service is the fundamental basis of exchange. \\
\hline Axioms 2/PF6 & The value is co-created by several actors, always including the beneficiary. \\
\hline Axioms 3/PF9 & All social and economic agents are resource integrators. \\
\hline Axioms 4/PF10 & Value is always unique and phenomenologically determined by the beneficiary. \\
\hline Axioms 5/PF11 & $\begin{array}{l}\text { Co-creation of value is coordinated through institutions generated by the actor and } \\
\text { institutional arrangements. }\end{array}$ \\
\hline & Source: adapted by the author of Vargo and Lusch (2016, p. 8). \\
\hline
\end{tabular}

When analyzing the historical trajectory of marketing thinking, it is possible to observe the evolution of consumer participation in market processes. The new theoretical discussions address the need to integrate the client into the process of creating value from the collaboration from their experiences with products and services. The value is no longer in the product, but in the experiences that the product provides and in the interaction between company and 
DOI: 10.14807/ijmp.v12i1.1301

consumer. Based on the dominant logic of the marketing service, the client becomes an active agent in creating value, a scenario that becomes perceived in private higher education.

Brambilla and Damacena (2011) complement that in a market where products and services increasingly resemble their characteristics, differentiation will take place through the creation of value perceived by the customer. This value will become a competitive advantage, transforming the service into a strategic activity.

From this new dominant logic of the service, the creation of value begins to occur through the system of exchange of experiences, proposing a narrative based on resource integration and provision of reciprocal service, with actors co-creating value for both parties, philosophy that should also be adopted by the educational market (Vargo \& Lusch, 2015).

Thus, value co-creation is no longer seen from a linear and sequential flow, but rather as a more complex and dynamic exchange system, similar to a service ecosystem, in which value creation practices are guided by institutions and arrangements as shown in Figure 1.

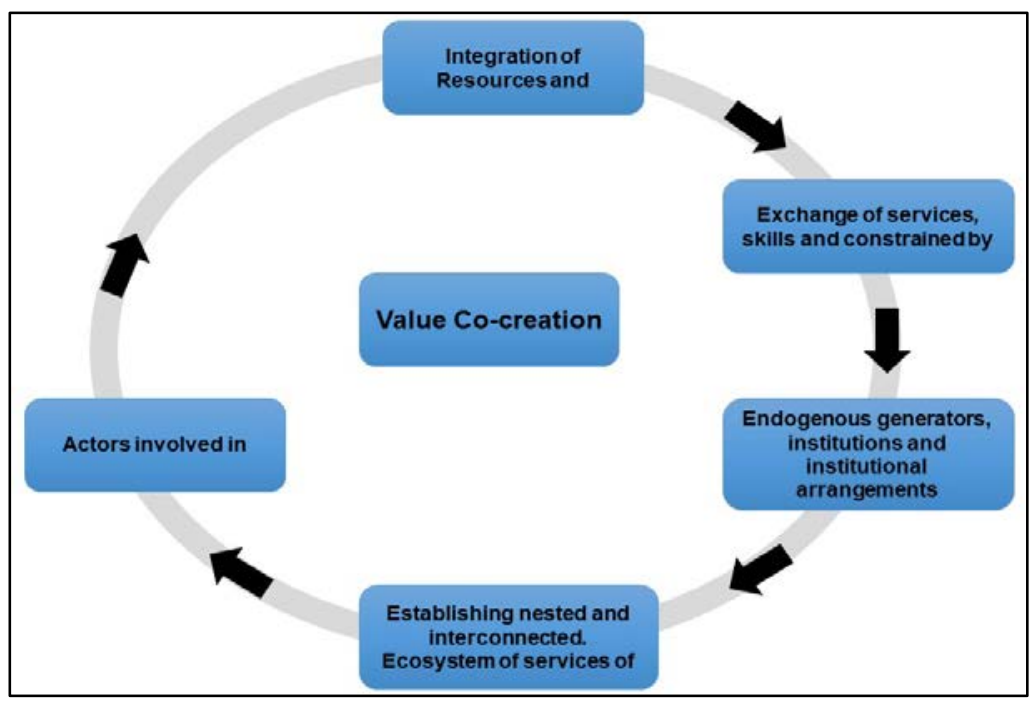

Figure 1: Narrative and process of the dominant logic of the service Source: adapted by the author of Vargo and Lusch (2016).

For Firat, Dholakia and Venkatesh (1995), the perception that consumers are actively engaged in creating value and benefits for consumption itself is in accordance with the postmodernist view that consumers are a participant in the "customization of a world." This point of view has affinity with the client concept as a part-time worker approached by Bowers, Martin and Luker (1990). For Grönroos and Ravald (2011), value creation, within the Dominant Logic of Service, is a process that seeks to create the value in use of resources for the consumer, culminating in different concepts of co-creation. 
DOI: 10.14807/ijmp.v12i1.1301

For a better understanding, this marketing logic, the SDL, is focused on the service. Therefore, the same "implies that marketing is a continuous series of social and economic processes" (Vargo \& Lusch, 2004a, p. 5). As can be seen in Table 3, the differences between product and service logics are substantial, and change the overview of market operation.

Table 3: Difference between LDP and LDS

\begin{tabular}{|c|c|c|}
\hline & \\
\hline & Product Oriented Marketing Logic & Service Oriented Marketing Logic \\
\hline First trading unit. & People trade for products. & $\begin{array}{l}\text { People exchange to acquire the } \\
\text { benefits of the service. }\end{array}$ \\
\hline Paper of products. & $\begin{array}{l}\text { Goods are material resources and end } \\
\text { products. }\end{array}$ & $\begin{array}{l}\text { Products are transmitters of } \\
\text { entrenched knowledge, used in the } \\
\text { co-creation of value. }\end{array}$ \\
\hline Role of consumers. & $\begin{array}{l}\text { The consumer is the recipient of the } \\
\text { products. }\end{array}$ & $\begin{array}{l}\text { The consumer is a co-creator of the } \\
\text { service. There is interaction. }\end{array}$ \\
\hline $\begin{array}{l}\text { Determination and } \\
\text { meaning of VALUE. }\end{array}$ & VALUE is determined by the producer. & $\begin{array}{l}\text { THE VALUE is perceived and } \\
\text { determined by the consumer. Firms } \\
\text { can only make value propositions. }\end{array}$ \\
\hline $\begin{array}{l}\text { Interaction between the } \\
\text { firm and the consumer. }\end{array}$ & The consumer is a target. & $\begin{array}{l}\text { Consumer is an active participant in } \\
\text { exchange relationships and also in the } \\
\text { co-creation of value. }\end{array}$ \\
\hline $\begin{array}{l}\text { Source of economic } \\
\text { growth. }\end{array}$ & $\begin{array}{c}\text { Wealth is obtained by tangible } \\
\text { resources. The reference unit is the } \\
\text { product. }\end{array}$ & $\begin{array}{l}\text { Wealth is obtained through } \\
\text { knowledge and specialized skills } \\
\text { (service). }\end{array}$ \\
\hline
\end{tabular}

Source: adapted by the author of Vargo and Lusch (2004a, p. 7) and Vargo and Lusch (2008).

Therefore, one of the ways to promote value to consumers is through co-creation, a concept that will be addressed below.

\section{VALUE CO-CREATION}

The co-creation of value makes the market an open space for dialogue between organizations and consumers. The market is now seen as a place to exchange experiences and consumers make clear their willingness to pay - or not, so it is being offered on the market (Prahalad \& Ramaswamy, 2004). As competitiveness increases, it is essential that service providers intensify the preparation of their personal contact team, both in the aspect of knowledge to provide the best possible service and service, as well as, in the aspect of elevating collaboration, relationship and interaction with customers (Bendapudi \& Leone, 2003; Prahalad \& Ramaswamy, 2004).

Following this logic, the consumer begins to be defined as an increasingly dynamic and participatory subject in the interaction with companies, prioritizing products that meet their needs and desires (Prahalad \& Ramaswamy, 2004). In order for the product to respond to the interests of the consumer, its participation in the creation process becomes fundamental. As 
DOI: 10.14807/ijmp.v12i1.1301

Prahalad and Ramaswamy (2000) have available, this involvement can be characterized as a co-creation of value, which has become increasingly common in the middle of business.

Conquering the client by meeting their most particular needs through co-creation, considering their needs and wills, can be the differential to generate satisfaction and assist in the positive perception of the same in relation to the company (Zmoginski et al., 2009). Prahalad and Ramaswamy (2004) argued that in the future, competitive advantage will be related to the process of co-creation of value with consumers. This interaction with the consumer is due to the offer of their skills, skills and, mainly, for their experiences of consumption. Thus, the consumer is considered as an active and endogenous agent in the marketing process (Lusch, 2007; Prahalad \& Ramaswamy, 2004).

Thus, the co-creation of value takes place through the active participation of the consumer in the development of a customized product and/or service that meets the needs and expectations. Thus, the essence of co-creation in service is the search for a better composition of value to the consumer, serving their interests in the individual plane, a situation that characterizes one of the discussions of the Dominant Logic of the Service (Brambilla \& Damacena, 2011). Table 4 shows some of the concepts of value co-creation.

Table 4: Concepts of value co-creation

\begin{tabular}{|l|l|}
\hline \multirow{3}{*}{} & $\begin{array}{l}\text { Consumers and other actors are part of the value creation process. It is the source for value } \\
\text { generation. Value is created collaboratively through the interaction of several actors, in order to } \\
\text { achieve the final result that meets all involved. }\end{array}$ \\
\cline { 2 - 3 } & Shared value creation that develops between company and consumer. \\
\cline { 2 - 3 } & Allow the consumer to participate in the co-construction of the service experience. \\
\cline { 2 - 3 } & Jointly defined the problem and also the solution. \\
\cline { 2 - 3 } & Varied experiences, the participation of different people. \\
\cline { 2 - 3 } & Individualized experience. \\
\cline { 2 - 3 } & Continuous dialogue between all parties involved in the co-creation process. \\
\cline { 2 - 3 } & Custom experience co-construction. \\
\hline
\end{tabular}

Source: Adapted by the author, Bambilla and Damacena (2011), based on Prahalad and Ramaswamy (2004) and Vargo and Lusch (2011).

According to Brazil, Santos and Dietrich (2010, p. 08), there are some principles that condition the co-creation of value, that is, "characteristics that would provide, or not, convenient conditions for generating value based on sharing and experiences". In order to demonstrate and provide the dissemination of knowledge to stakeholders, the authors designed a structure that, in accordance with the organizational structure, establishes elements that enable, sustain and make possible the implementation of the co-creation process within organizations, so that the objectives of both parties can be achieved (client and organizations). 
DOI: 10.14807/ijmp.v12i1.1301

In the design of value co-creation, there is no clear distinction of roles between clients and organizations proposed by the traditional approach of value creation. Cova and Dalli (2009) point out that, although it is already clear that consumers contribute to the social construction of reality, culture and consumer symbology, there is still a need to explain that they also produce economic value through the collaboration with companies. For authors, consumers are the main source of value and therefore value co-creators.

The process of co-creation of customer value is based on the experience of the relationship that the customer experiences or experienced with the company's products and services. This meeting is what allows interaction between both parties, when everyone collaborates for the co-creation of value. This experience is influenced by several factors, which can be emotional (feelings, mood, personality characteristics), cognitive (developed through the processing of information present in memory) or behavioral (actions that originate and result in experiences) (Payne, Storbacka \& Frow, 2008).

Thus, after this review in the conceptual models proposed by Prahalad and Ramaswamy (2004) and Payne, Storbacka and Frow (2008), it can be affirmed that the relationships established between client/consumer and company are the essence of value co-creation. Ramaswamy and Gouillart (2010) emphasize that co-creating value with the customer or final consumer cannot be considered as the only way for a company to develop this process, and it is necessary to involve all stakeholders in it, enabling interaction between consumers and managers, but also suppliers and employees. According to the authors, providing innovative experiences for end customers/consumers requires the company to have a highly qualified internal team.

Ramaswamy (2009) contributes to studies stating that it is necessary to understand the roles of each of the co-creators, operating, where necessary, in response to the needs and desires of customers/consumers and also of other stakeholders. From an organizational point of view, the author states that all employees should be involved in the process, "from the first contact with the client, to the after-sales", thus will be creating an environment conducive to cocreation between client and company.

\subsection{Services Based on Value Co-creation: A Master's Study in Administration}

Given the importance of premises oriented to the Logic of The Service in Marketing, that of the consumer as a co-creator of value, is one of the most relevant. Because it is important 
DOI: 10.14807/ijmp.v12i1.1301

to point out the complexity of educational services offered by private higher education institutions.

In this sense, the importance of co-creation for the generation of value, more precisely in the Master's degree in Administration course at a University located in Rio Pardo Valley / RS, in which the institution is a service provider, and it responds by the performance for the minimum performance of approval and professional training of these students in the future. Reports were collected aiming to clarify the co-creation of value in private higher education, some interviews with teachers (teachers) and students (students) of the Master's Course in Administration at a University located in the Vale do Rio Pardo/RS, which has an average of 20 students annually attending this course.

Of the reports collected in the last quarter of 2018, five considerations from each category were selected about the interactions between teacher and student in the master's class in administration. Each contribution will be reported according to the interviewees' speech during this chapter, whose generic identification of the report may be: "teacher" or "student".

- Teacher 1: The role of the teacher is to discuss and present the main theoretical approaches, as well as instigate the debate with students. The initial report indicates that in the service, the co-creation of value in education, results in the meeting in which the educational institution through its faculty (teachers) needs to promote mechanisms that can instigate the debate on the themes proposed within of the classroom.

- Teacher 2: Forming an ethical, critical subject, and who knows his responsibility. In this report, the role of the teacher goes beyond his role as an educator, that is, the same contributes to train subjects who need to build their own personality in this process of ethical and moral values, which are fundamental for the construction of each Individual.

- Teacher 3: The learning process is not completely individual that requires interaction. In this statement, learning depends not only on the students, but on the engagement of the teacher who contributes to their training. Thus, the interaction between teacher and student from the perspective of value co-creation results in the creation of knowledge between the parties involved in this process.

- Teacher 4: The teacher is a builder of knowledge along with the student. The teacher's challenge in recent years has ceased to be a mere replicator of knowledge, because it is up to the teacher to bridge the student and the various ways of teaching, that is, together 
DOI: 10.14807/ijmp.v12i1.1301

teacher and student learn, because the greater the involvement between teachers and higher students will be the chances of building new knowledge.

- $\quad$ Teacher 5: The teacher who teaches the discipline needs to follow the basic menu of the discipline, and the contents that were approved by the educational institution and Capes. In this report, the university provides the teacher with the menu of a certain discipline that it will teach, but it is up to the professor in addition to following the programmatic content, seeking new ways to pass the content within the classroom, because innovating is one of the practices proposed in studies related to co-creation of value in the educational context.

In addition to reports collected with teachers, reports were collected with students of the Master's degree in Administration, then five reports were highlighted:

- Student 1: Develop knowledge in the best possible way, and bring in a reworked way this issue of teaching. From this report the student seeks to develop new knowledge, where it promotes a change of mentality, the way of thinking, in order to ensure even a better quality of learning, and, contributing to new teaching methods.

- Student 2: Very important for my professional growth. In this report, the possibilities of growth are immense. Therefore, it is important as university academics to seek specific certifications in the areas that are intended to act as a professional, since it will basically have their personal effort to grow.

- Student 3: When the service is offered with quality, it is an investment that is made in your life. In this testimony, the student should be aware of everything when choosing a quality educational service, because who determines whether the quality of a service is good or not the client (student), being the quality of educational services provided indispensable at the time of choose by particular university and course.

- Student 4: But there are many people who are wearing the institution's shirt, and who are really partners of the educational institution and who makes "the thing happen". It is perceived in this report that it should not invalidate the fact that the purpose of the educational institution is only to profit, but on the other hand there is the idea of the concept of social responsibility of the educational institution towards the community in which it is inserted, as well as people committed to making a difference in academia. 
DOI: 10.14807/ijmp.v12i1.1301

- Student 5: It is important, because the construction of knowledge is not only within the classroom. This account in turn is understood that the construction of knowledge depends not only on students, but also in conjunction with teachers. Thus, the learning that is obtained within the classroom can be extended to other spaces of the university, such as large spaces of coexistence, libraries, among others. For, from the perspective of the coexistence of value, the involvement between groups of people provides debates, exchanges of information and experiences that provides different forms of knowledge construction.

Thus, it is perceived that although the expression co-creation of value is not present in the reports of teachers (teachers) and students (students), it is possible to identify the importance of this process in the reports of this group. In this sense, presented the central concepts of the evolution of the concept of marketing, dominant logic of the service, cocreation of value, as well as the example of the master's classroom in Administration at a University located in the Rio Pardo Valley/RS, follows the final considerations about the subject.

\section{FINAL CONSIDERATIONS}

The present study responded by a theoretical essay for a better understanding about the Dominant Logic of Marketing Service, seeking to make a rescue of the concepts and premises that guide marketing theories focused on services, based on studies initiated by exponents such as Vargo and Lusch in 2004. Because The SDL is a conceptual structure based on products and/or services, where it includes all the experiences involved throughout the co-creation process.

As a central pillar of studies based on the dominant logic of marketing service, the idea of working product and/or service together consists of resuming the understanding of marketing activities, providing the construction of strategies aimed at building competitive advantage. Pointing to the reports of teachers (teachers) and students, where both parties are concerned with the interaction, thus having an opportunity in the adoption of the SDL and in the co-creation of value based on innovation strategies focused on educational services offered by universities.

Thus, the action through this vision requires a managerial posture strategically focused on the interactions and possibilities of groups of people in helping to draw the experience experienced (Mendonça \& Medeiros, 2014). For example, in the case of higher education, the 
DOI: 10.14807/ijmp.v12i1.1301

main objective of the university is to pass on knowledge and contribute to the teaching process learning of these students, seeking to meet their expectations, when they chose to purchase a certain educational service of a university. Within this context of supply and demand, education often becomes seen as a service and the student as a client (SILVA et al., 2019).

It is also mentioned by Webster Jr. (2006), that the model of service-oriented logic in marketing represents an exciting, important and controversial discussion necessary for the development of the area. A theoretical line that breaks with traditional visions, which configure much of the development of Marketing. These discussions will result in changes, guiding the field to a new or modified conceptual posture, an integrated marketing sense (Webster Jr., 2006). As a minimum, the dominant logic of the service will provide discussions that tend to advance discipline to integrative issues and essential precepts in the new competitive scenarios.

Regarding the theoretical contribution, it can be perceived that the studies of Ciccantelli and Magison (1993), Nambisam (2002); Prahalad and Ramaswany (2004) suggest that companies need to co-create value to gain an advantage over their competitors, a situation, which has been identified even more expressively since the second decade of the 21st century. Thus, the analysis of information was developed based on the assumption that the dominant logic of service and the co-creation of value can favor the strengthening of the company from the relationship between company and client.

Finally, the realization of this research also resulted in some aspects that need to be mentioned: it presents an important contribution in marketing administration, by contextualizing concepts and premises of the dominant logic of service. Furthermore, the cocreation of value in complex service in the Master's degree in Administration course at a University located in the Rio Pardo Valley/RS was considered, bringing reports of professors and students related to the interaction between the two in the classroom of this course.

As a limitation of the study, I highlight that the sample used included only one unit of analysis, that is, the classroom of a graduate program in administration of a University located in the Vale do Rio Pardo/RS, in which it had reports from professors (teachers) and students (students). As a stimulus for new studies, it is recommended to contemplate more units of analysis, as well as other educational institutions.

\section{REFERENCES}

Alves, H., \& Raposo, M. (2007). Conceptual model of student satisfaction in higher education. Total Quality Management, 18(5), 571-588. 
DOI: 10.14807/ijmp.v12i1.1301

Ballantyne, D., \& Varey, R. J. (2006). Creating value-in-use through marketing interaction: the exchange logic of relating, communicating and knowing. Marketing theory, 6(3), 335348.

Ballantyne, D. (2004). Dialogue and its role in the development of relationship specific knowledge. Journal of Business \& Industrial Marketing, 19(2), 114-123.

Baker, M., \& Hart, S. (2008). O livro de marketing. Routledge.

Barguil, F. E. (2012). O papel da confiança na coprodução (Doctoral dissertation).

Bendapudi, N., \& Leone, R. P. (2003). Psychological implications of customer participation in co-production. Journal of marketing, 67(1), 14-28.

Bendapudi, N., \& Leone, R. (2001). How to Lose Your Star Performer Without Losing Customers, Too. Harvard Business Review, 79(10), 104-110.

Berry, L. L., Carbone, L. P., \& Haeckel, S. H. (2002). Managing the Total Customer Experience. MIT Sloan Management Review, 43(3), 84-90.

Berry, L. L. (1987). Big Ideas in Services Marketing. Journal of Services Marketing, 1(1), 5-9.

Best, R. J. (2009). Market-based management: Strategies for growing customer value and profitability.

Bolton, R. N., Grewal, D., \& Levy, M. (2007). Six Strategies for Competing through Service: An Agenda for Future Research. Journal of Retailing, 83, 1-4.

Bowers, M. R., Martin, C. L., \& Luker, A. (1990). Trading places: employees as customers, customers as employees. Journal of Services Marketing, 4(2), 55-69.

Brambilla, F. R. (2013). Perspectiva Multi-Canal de valor na lógica dominante do serviço em Marketing. Diálogo, (24), 105-114.

Brambilla, F. R., \& Damacena, C. (2011). Lógica Dominante do serviço em marketing: estudo dos conceitos e premissas aplicados à educação superior privada na perspectiva docente. Revista Brasileira de Marketing, 10(3), 151-176.

Brambilla, F. R. (2010). Entendendo a lógica dominante do serviço em marketing: conceito e premissas. Encontro Anual da Associação de Pós-Graduação em Administração, 34.

Brasil, V. S., Santos, C., \& Dietrich, J. F. (2010). Co-Criação de valor: proposição de uma estrutura de análise dos elementos influenciadores da criação compartilhada de valor nas empresas. Anais do EMA-IV Encontro de Marketing da ANPAD, Florianópolis.

Chen, C., \& Hughes, J., Jr. (2004). Using Ordinal Regression Model to Analize Student Satisfaction Questionnaires. Association for Institutional Research - AIR: IR

Applications, 1(1), 1-12.

Ciccantelli, S., \& Magidson, J. (1993). From experience: consumer idealized design: involving consumers in the product development process. Journal of product innovation management, 10(4), 341-347.

Cova, B., \& Dalli, D. (2009). Working consumers: the next step in marketing theory?. Marketing theory, 9(3), 315-339.

D’avila, L. C., Damacena, C.; Garrido, I. L. (2008). Valor de Marca na Nova Lógica de Serviços. Anais do XXXII EnANPAD. Rio de Janeiro: Anpad. 
Darroch, J.; Miles, M. P., Jardine, A., \& Cooke, E. F. (2004). The 2004 AMA definition of marketing and its relationship to a market orientation: an extension of Cooke, Rayburn, \& Abercrombie (1992). Journal of Marketing Theory and Practice, 12(4), 29-38.

Day, G. S., Deichton, J., \& Narayandas, D. (2004). Invited Commentaries on 'Evolving to a New Dominant Logic for Marketing'. Journal of Marketing, p. 18-27.

Debnath, S. C., Tandon, S., \& Pointer, L. V. (2007). Designing Business School Courses to Promote Student Motivation: An Application of the Job Characteristics Model. Journal of Management Education, 31(6), 812-831.

Mendonça, F. M., \& Medeiros, M. L. (2014). Satisfação e lógica dominante do serviço em meios de hospedagem. Revista Hospitalidade, 246-270.

Moraes, M. B., \& Costa, B. K. (2012). Co-criação de valor e perspectiva da lógica dominante: um estudo em uma empresa do setor aeronáutico. Revista Brasileira de Gestão e Desenvolvimento Regional, 9(2).

Etierre, M. (2018). Processo Cocriativos Entre Empresa, Atleta e Consumidores. Dissertação (Dissertação em Administração) - UNISC. Santa Cruz do Sul.

Fang, C. B., Candelária, P. D. A. P., Klug, W. A., \& Capelhuchnik, P. (2008). Surgical treatment of rectal prolapse by the Delorme technique and rectopexy. Revista da Associação Médica Brasileira, 54(2), 142-145.

Faria, A. (2008). A evolução do conceito de marketing. Rio de Janeiro: FGV Online.

Fitzsimmons, J. A., \& Fitzsimmons, M. J. (2014). Administração de Serviços: Operações, Estratégia e Tecnologia da Informação. Amgh Editora.

Firat, A. F., Dholakia, N., \& Venkatesh, A. (1995). Marketing em um mundo pósmoderno. Revista Europeia de Marketing, 29(1), 40-56.

Grönroos, C. (2006). Adopting a service logic for marketing. Marketing theory, 6(3), 317333.

Grönroos, C., \& Voima, P. (2013). Critical service logic: making sense of value creation and co-creation. Journal of the academy of marketing science, 41(2), 133-150.

Grönroos, C., \& Ravald, A. (2011). Service as business logic: implications for value creation and marketing. Journal of service management, 22(1), 5-22.

Hertog, P. D., Wietze, A. V. D., \& Jong, M. (2010) Capabilites for managing service innovation: towards a conceptual framework. Journal of Service Management, v. 21, n. 4, p. 490-514.

Lazzaretti, T. M. (2013). Valor Percebido e a Nova Lógica Dominante de Serviço: estudo da indústria brasileira de equipamentos de refrigeração para transporte de cargas (Doctoral dissertation).

Levitt, T. (1960). Marketing Myopia. Harvard Business Review, v. 38 (July-August), n. 4 p. 26-44.

Lusch, R. F. (2007). Marketing's evolving identity: defining our future. Journal of Public Policy \& Marketing, 26(2), 261-268.

Lusch, R. F., \& Vargo, S. L. (2014). The service-dominant logic of marketing: Dialog, debate, and directions. Routledge. 
DOI: 10.14807/ijmp.v12i1.1301

Lusch, R. F., Vargo, S. L., \& OBrien, M. (2007). Competing through Service: Insights from Service-Dominant Logic. Journal of Retailing, 83(1), 5-18.

Lusch, R. F., \& Vargo, S. L. (2006a) Service-Dominant Logic: Reactions, Reflections and Refinements. Marketing Theory, 6(3), 281-288.

Lusch, R. F., \& Vargo, S. L. (2006b). The Service-Dominant Logic of Marketing: Dialog, Debate, and Directions. New York: M. E. Sharpe.

Kotler, P., \& Levy, S. J. (1969). Ampliando o conceito de marketing. Jornal de marketing, 33 (1), 10-15.

Maglio, P. P., \& Spohrer, J. (2013). A service science perspective on business model innovation. Industrial Marketing Management, 42(5), 665-670.

Moraes, M. B., \& Costa, B. K. (2013). Co-criação de valor e perspectiva da lógica dominante: um estudo em uma empresa do setor aeronáutico. Revista Brasileira de Gestão e Desenvolvimento Regional, 9(2).

Nambisam, S. (2002). Designing virtual customer environments for new product development: Toward a theory. Academy of Management review, 27(3), 392-413.

Oliveira, G., Damacena, C., \& Brambilla, F. R. (2014). Cocriação como proposta para geração de valor: caso da empresa dental américa. Desenvolve Revista de Gestão do Unilasalle, 3(2), 129-150.

Payne, A. F., Storbacka, K., \& Frow, P. (2008). Managing the co-creation of value. Journal of the academy of marketing science, 36(1), 83-96.

Pine, B. J., \& Gilmore, J. H. (1998). Welcome to the experience economy. Harvard business review, 76, 97-105.

Prahalad, C. K., \& Ramaswamy, V. (2004). Co-Creation Experiences: The Next Practice in Value Creation. Journal of Interactive Marketing, 18(3), 5-14.

Prahalad, C. K., \& Ramaswamy, V. (2003). The New Frontier of Experience Innovation. MIT Sloan Management Review, 12-18.

Prahalad, C. K., \& Ramaswamy, V. (2000). The future of competition: Co-creating unique value with customers. Harvard Business Press.

Ramaswamy, V. (2003). Co-creating experiences with customers: new paradigm of value creation. The TMTC Journal of Management, 8, 6-14.

Ramaswamy, V. (2009). Liderando a transformação para co-criação de valor. Estratégia e Liderança, 37 (2), 32-37.

Ramaswamy, V., \& Gouillart, F. J. (2010). O poder da co-criação: construa com eles para impulsionar o crescimento, a produtividade e os lucros. Simon e Schuster.

Ribeiro, Á. H. P., Monteiro, P. R. R., \& Luttembarck, L. (2019). The Use of the'Job to Be Done'methodology to identify value co-creation opportunities in the context of the Service Dominant Logic. BBR. Brazilian Business Review, 16(1), 32-45.

Ritala, P., Hurmelinna-Laukkanen, P., \& Blomqvist, K. (2009). Tug of war in innovationcoopetitive service development. International Journal of Services Technology and Management, 12(3), 255-272.

Rocha, A., \& Christensen, C. (1999). O conceito de marketing. Rocha, A., \& Christensen, C. Marketing: teoria e prática no Brasil. São Paulo: Atlas. 
DOI: 10.14807/ijmp.v12i1.1301

Sawhney, B., Balasubramanian, S., \& Krishnan. (2004). Criando crescimento com serviços. MIT Sloan Management Review.

Sheth, J. N., \& Uslay, C. (2007). Implications of the revised definition of marketing: from exchange to value creation. Journal of Public Policy \& Marketing, 26(2), 302-307.

Silva, M., Silva, L. C. A., Fontoura, F. B. B., \& Brambilla, F. R. (2019). Cocriação de valor e comportamento do consumidor no ensino superior privado. CPMark - Caderno Profissional de Marketing - UNIMEP, 7(1).

Terblanche, N. S. (2005). A century of marketing: Achievements, mishaps and future challenges. Management Dynamics: Journal of the Southern African Institute for Management Scientists, 14(4), 2-17.

Thomke, S., \& Von Hippel, E. (2002). Clientes como inovadores: uma nova maneira de criar valor. Revisão de negócios de Harvard, 80(4), 74-85.

Vargo, S. L., \& Lusch, R. F. (2016). Instituições e axiomas: uma extensão e atualização da lógica dominante de serviço. Jornal da Academia de Marketing Science, 44(1), 5-23.

Vargo, S. L., \& Lusch, R. F. (2008b). Why service? Journal of the Academy of Marketing Science, 36(1), 2538.

Vargo, S. L., \& Lusch, R. F. (2008). Service-Dominant Logic: Continuing the Evolution. Journal of the Academy of Marketing Science, 36, 1-10.

Vargo, S. L., \& Lusch, R. F. (2007). Robert F. Why Service? Academy of Marketing Science, 36, 25-38.

Vargo, S. L., \& Lusch, R. F. (2004a). Evolving to a New Dominant Logic for Marketing. Journal of Marketing, 68, 1-17.

Vargo, S. L., \& Lusch, R. F. (2004b). The Four Service Marketing Myths: Remnants of a GoodsBased, Manufactoring Model. Journal of Service Research, 6(4), 324-335.

Vargo, S. L., Lusch, R. F., \& Morgan, F. W. (2006). Historical Perspectives on ServiceDominant Logic. In: Lusch, R. F., \& Vargo, S. L. (Editors). The Service-Dominant Logic of Marketing: Dialog, Debate, and Directions. New York: M. E. Sharpe, 29-42.

Vargo, S. L., \& Morgan, F. W. (2005). Services in Society and Academic Thought: An Historical Analysis. Journal of Macromarketing, 25(1), 42-53.

Vargo, S. L., \& Akaka, M. A. (2009). Service-dominant logic as a foundation for service science: clarifications. Service Science, 1(1), 32-41.

Vargo, S. L., Maglio, P. P., \& Akaka, M. A. (2008). Na co-criação de valor e valor: uma perspectiva de sistemas de serviço e lógica de serviço. Revista europeia de gestão, 26(3), 145-152.

Von Hippel, E. (1986). Usuários líderes: uma fonte de novos conceitos de produtos. Management science , 32(7), 791-805.

Voss, R.;, Gruber, T., \& Szmigin, I. (2007). Service Quality in Higher Education: The Role of Student Expectations. Journal of Business Research, 60, 949-959.

Webster, Jr., \& Frederick E. (2006). Foreword. In: Lusch, Robert F., \& Vargo, Stephen L. (Editors). The Service-Dominant Logic of Marketing: Dialog, Debate, and Directions. New York: M. E. Sharpe, p.xiii-xv. 
ISSN: 2236-269X

DOI: 10.14807/ijmp.v12i1.1301

Zmoginski, A. S., Kwak, A. I. B., Canabarra, C. M., Bertolino, D. F., Ynonye, F. Y., \& Ades, C. (2009). Co-criação de Valor: Inovação no Modelo de Negócio Obtendo Vantagem Competitiva. Revista Jovens Pesquisadores. Vi(10). 